\title{
Analisis Deskriptif ISPA pada Anak dan Balita di Pulau Moti
}

\author{
Marhaeni Hasan*1, Fera The ${ }^{2}$ \\ 1,2 Program Studi Pendidikan Dokter, Fakultas Kedokteran, Universitas Khairun, Indonesia \\ Email: ${ }^{* 1}$ nenisaga@gmail.com; 2fera_the@yahoo.com
}

\author{
Received :26-02-2020 \\ Accepted :30-04-2020 \\ Available online :31-05-2020
}

\begin{abstract}
ABSTRAK
ISPA terus menjadi penyebab utama kematian pada bayi dan anak usia di bawah lima tahun di seluruh dunia. ISPA bertanggung jawab atas kematian sekitar 3,9 juta anak di seluruh dunia setiap tahunnya. Dilaporkan sekitar $40 \%$ dari total kematian akibat ISPA di seluruh dunia terjadi di Bangladesh, India, Indonesia, dan Nepal. Hasil laporan Riset Kesehatan Dasar (Riskesdas) tahun 2013 menunjukkan prevalensi ISPA di Indonesia masih cukup tinggi yakni sebesar 25\%. Prevalensi tertinggi terjadi pada balita $(25,8 \%)$ dan bayi $(22 \%)$. Penelitian ini bertujuan mengetahui faktor-faktor yang mempengaruhi kejadian Infeksi Saluran Pernapasan Akut (ISPA) pada anak 0-5 tahun di Pulau Moti. Penelitian ini menggunakan observasional dengan menggunakan pendekatan Cross Sectional. Sampel yang digunakan sebanyak 100 orang dengan kisaran umur 0-5 tahun. Data yang digunakan berupa kuesioner. Hasil penelitian menunjukkan tingkat pendidikan responden dengan persentase tertinggi adalah lulusan Sekolah dasar (SD) sebesar $38 \%$, sedangkan persentase menurut perkerjaan, yang menempati persentase tertinggi adalah ibu rumah tangga (83\%). Faktor lainnya yang terekam adalah karakteristik biologi, riwayat penyakit dan pengobatan, serta kondisi lingkungan. Mayoritas balita lahir dengan berat badan diatas 2500 gram (89\%), imunisasi lengkap 81\%, pemberian ASI eksklusif juga sudah mencapai angka $76 \%$, kurang lebih $81 \%$ balita hidup pada keluarga yang memiliki kebiasaan merokok, sebanyak 79\% responden masih menggunakan bahan bakar untuk kebutuhan memasak, dan $80 \%$ kondisi lingkungan tempat tinggal orang tua balita dikategorikan berdebu. Kesimpulan penelitian ini yaitu faktor risiko yang paling mempengaruhi kejadian ISPA pada balita di Pulau Moti adalah faktor lingkungan, yaitu tingkat kepadatan hunian, kondisi rumah yang berdebu, penggunaan kayu bakar sebagai bahan bakar untuk memasak, serta kebiasaan merokok anggota keluarga dalam rumah.
\end{abstract}

Keywords: ISPA, deskriptif, balita, pulau Moti

\section{ABSTRACT}

Acute Respiratory Infection (ARI) continues to be the leading cause of death in infants and children under the age of five throughout the world. ARI is responsible for the deaths of around 3.9 million children worldwide each year. It was reported that around $40 \%$ of total deaths from ARI around the world occurred in Bangladesh, India, Indonesia, and Nepal. The results of the 2013 Basic Health Research (Riskesdas) report showed that the prevalence of ARI in Indonesia is still quite high at $25 \%$. The highest prevalence occurred in infants $(25.8 \%)$ and infants $(22 \%)$. This study aims to determine the factors that influence the incidence of acute respiratory infections (ARI) in children 0-5 years on Moti Island. This study uses an observational study using a crosssectional approach. The samples used were 100 people with an age range of 0-5 years. The data used in the form of a questionnaire. The results showed that education occupying the highest percentage was elementary school (SD) graduates, 38\%, while the percentage according to employment was as follows, the highest percentage was housewives $(83 \%)$, the majority of toddlers born weighing over 2500 grams $(89 \%)$, complete immunization $81 \%$, exclusive 


\section{TECHNO: Vol. 09 (01) Mei 2020}

breastfeeding has also reached $76 \%, 81 \%$ of these toddlers live in families who have smoking habits, $79 \%$ of respondents still use fuel, $80 \%$ of parents whose environment around the house is dusty. The conclusion that can be drawn is the risk factors that most influence the incidence of ARI in infants on Moti Island are environmental factors, namely the level of occupancy density, dusty house conditions, the use of firewood as fuel for cooking, and smoking habits of family members in the house.

Keywords: Acute respiratory infection, descriptive, toddler, moti island

\section{PENDAHULUAN}

Infeksi saluran pernapasan akut merupakan infeksi yang terjadi pada saluran pernapasan bagian atas maupun bawah yang disebabkan oleh virus dan bakteri yang menyebabkan inflamasi. Saluran pernapasan bagian atas yang dimaksud adalah suatu sistem saluran bercabang yang luas, dimulai dari lubang hidung hingga bagian ujung bawah kartilago krikoid (Mucia et al., 2015). Virus yang paling sering menyebabkan ISPA pada balita adalah Influenza- $A$, adenovirus, dan Parainfluenza virus. Proses patogensis berhubungan dengan tiga faktor utama, yaitu keadaan imunitas, jenis patogen, dan berbagai faktor yang saling berinteraksi. Infeksi Saluran Pernapasan Akut (ISPA) termasuk air borne disease yang penularannya terjadi melalui udara. Penyakit ini dapat menyerang orang dengan berbagai usia, tetapi yang paling sering adalah bayi, balita, dan manula (Lebuan \& Somia, 2014). Beberapa faktor risiko terjadinya ISPA adalah faktor lingkungan, ventilasi, kepadatan hunian, umur, berat badan lahir, status imunisasi, dan faktor perilaku (Novesar et al., 2014).

ISPA terus menjadi penyebab utama kematian pada bayi dan anak usia di bawah lima tahun di seluruh dunia (Jamison et al., 2006: Simoas, EAF., et.al. 2017). ISPA bertanggung jawab atas kematian sekitar 3,9 juta anak di seluruh dunia setiap tahunnya. Dilaporkan sekitar 40\% dari total kematian akibat ISPA di seluruh dunia terjadi di Bangladesh, India, Indonesia, dan Nepal (Marciniuk et al., 2014; Solomon et al., 2018). Pneumonia merupakan penyakit ISPA yang disebabkan oleh bakteri yang paling banyak menyebabkan kematian yaitu sekitar $90 \%$. Kejadian pneumonia di negara maju hanya sekitar 3-4\% sedangkan di negara berkembang 20$30 \%$. Perbedaan ini terjadi akibat malnutrisi, berat bayi lahir yang rendah, dan polusi udara (Marciniuk et al., 2014; Taksande \& Yeole, 2015).

Di Indonesia ISPA masih merupakan masalah kesehatan yang penting karena Indonesia menduduki peringkat ke-6 di dunia untuk kasus pneumonia pada balita pada tahun 2006 dengan jumlah penderita 6 juta orang. ISPA juga selalu menempati urutan pertama untuk penyebab kematian pada balita, selain itu sering pula masuk dalam daftar 10 penyakit terbanyak (Novesar et al., 2014). Hasil laporan Riset Kesehatan Dasar (Riskesdas) tahun 2013 menunjukkan prevalensi ISPA di Indonesia masih cukup tinggi yakni sebesar $25 \%$. Prevalensi tertinggi terjadi pada balita $(25,8 \%)$ dan bayi $(22 \%)$.

Penyakit berbasis lingkungan menjadi penyebab utama kematian di Indonesia. ISPA menduduki peringkat pertama dengan 15,7\% kematian, selanjutnya TBC 9,6\%, dan diare 7,4\%. Secara total, penyakit berbasis lingkungan menyumbang 33\% atau sepertiga total kematian seluruh umur. Indonesia merupakan negara kepulauan yang ditandai dengan banyaknya pulau dengan garis pantai yang panjang sehingga masalah kesehatan lingkungan di Indonesia masih sangat memprihatinkan. Hal ini ditandai dengan kurangnya sanitasi di daerah 
kepulauan dan tingginya angka kesakitan akibat penyakit infeksi atau menular (Rahman \& Ma'wa, 2015).

Data dari Laporan Penyakit Kasus tertinggi di Puskesmas Moti didapatkan jumlah kasus di Pulau Moti dengan presentasi 1332 orang tahun 2017, 909 orang tahun 2018 dan 955 orang tahun 2019. Data tersebut menunjukkan adanya peningkatan presentasi kasus ISPA pada 2 tahun terakhir. Berdasarkan data tersebut, perlu dilakukan penelitian untuk memperoleh gambaran tentang faktor resiko ISPA agar dapat dijadikan acuan dalam pembuatan model penanganan secara komprehensif.

\section{METODE PENELITIAN}

Penelitian ini dilaksanakan di Pulau Moti Kota Ternate Provinsi Maluku Utara seperti ditunjukkan pada Gambar 1.

\section{Prosedur Penelitian}

a. Jenis Penelitian

Jenis penelitian ini adalah observasional dengan menggunakan pendekatan Cross Sectional. Penelitian ini menggunakan metode kuantitatif dengan cara purposive sampling. Pemilihan lokasi penelitian (Pulau Moti) dengan pertimbangan tingginya kejadian ISPA di daerah ini (data 2 tahun terakhir). Populasi dalam penelitian ini adalah semua ibu yang mempunyai bayi usia 0 - 5 tahun.

b. Tahapan Penelitian

Penelitian ini diawali dengan survey ke Pulau Moti untuk mendapatkan jumlah keluarga yang memiliki anak 0-5 tahun yang pernah mengalami ISPA. Setelah itu menetapkan sampel berdasarkan kriteria inklusi

1. Bertempat tinggal di pulau Moti

2. Bersedia menjadi responden penelitian.

3. Ibu yang mempunyai bayi usia 0-5 tahun yang pernah mengalami ISPA

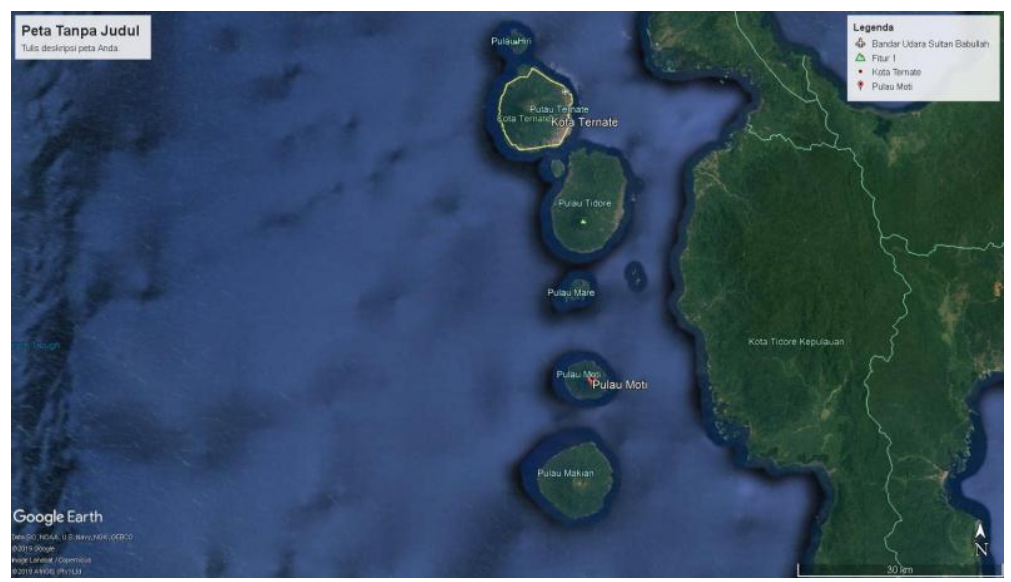

Gambar 1. Lokasi Penelitian

\section{Pengumpulan Data}

a. Data Primer

Data primer diperoleh melalui wawancara langsung kepada responden (ibu anak) yang bersedia diwawancarai berdasarkan kuesioner yang telah dirancang sebelumnya. 


\section{b. Data Sekunder}

Data sekunder digunakan sebagai penunjang dan pelengkap dari data primer. Data ini meliputi data gambaran geografis dan demografis tempat penelitian yang diperoleh dari Pulau Moti

\section{Pengolahan Data dan Analisis Data}

Seluruh kuesioner yang telah dikumpulkan kemudian dilakukan beberapa tahap pengolahan data, meliputi:

a. Editing

Bertujuan untuk meneliti data yang telah diperoleh dari hasil wawancara menggunakan kuesioner.

b. Skoring

Pemberian nilai atau skor untuk jawaban dari pertanyaan dalam kuesioner.

c. Coding

Bertujuan untuk memberi kode angka pada masing-masing data atau variabel.

d. Entry Data

Bertujuan untuk memasukkan data mentah dalam suatu sistem pengolahan data untuk dianalisa.

e. Tabulating

Bertujuan untuk memasukkan data hasil penelitian ke dalam tabel sesuai kriteria. Setelah data ditabulasi, selanjutnya dilakukan analisa univariat, bertujuan untuk mengetahui gambaran terhadap variabel yang diteliti. Pada analisa ini menghasilkan distribusi dan persentase dari tiap variabel.

\section{HASIL DAN PEMBAHASAN}

Data dari Puskesmas Moti menunjukkan jumlah kasus ISPA dari tahun 2017-2019 yaitu 1332 orang (tahun 2017), 909 orang (tahun 2018), dan 955 orang (tahun 2019). Data tersebut menunjukkan adanya peningkatan presentasi kasus ISPA pada 2 tahun terakhir. Dari data yang didapatkan tersebut, dilakukan penelitian mengenai faktor-faktor yang menyebabkan tingginya kejadian ISPA di daerah tersebut. Salah satu variabel dalam penelitian ini adalah lingkungan sosial, berupa tingkat pendidikan dan pekerjaan orang tua balita dan bayi. Informasi tingkat pendidikan responden, tersaji pada Gambar 2 berikut.

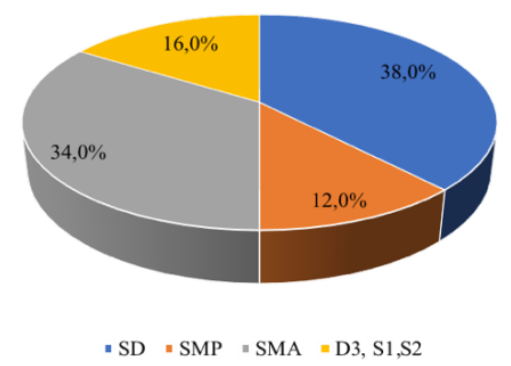

Gambar 2. Grafik Tingkat Pendidikan Responden

Berdasarkan Gambar 2, dapat dijelaskan bahwa umumnya orang tua bayi dan balita di Pulau Moti memiliki tingkat pendidikan adalah lulusan Sekolah Dasar (SD) (38\%), kemudian diikuti lulusan SMA (34\%), lulusan D3/S1/S2 (16\%), dan terakhir SMP (12\%). Sedangkan informasi responden berdasar perkerjaan, yang menempati persentase tertinggi adalah ibu rumah 
tangga (83\%), PNS (6\%), Petani/Nelayan (6\%), dan terakhir yaitu pegawai honor \& swasta (5\%), sebagaimana ditunjukkan pada Gambar 3 berikut.

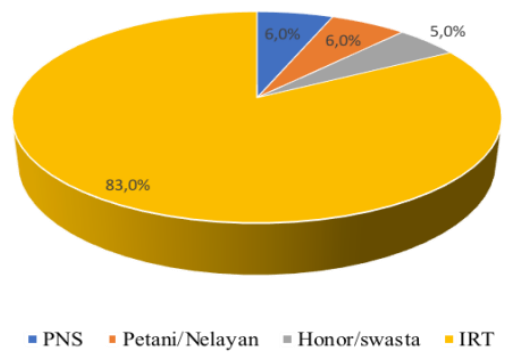

Gambar 3. Grafik berdasarkan profesi responden

Tingkat pendidikan mempengaruhi rasa antusias seorang ibu untuk mencari informasi tentang kesehatan dan menerapkan pola hidup yang sehat. Selain tingkat pendidikan, adapula faktor pekerjaan. Seorang ibu yang bekerja (wanita karier), memiliki waktu lebih sedikit untuk mengurus anaknya, dibandingkan dengan ibu yang tidak bekerja. Namun dalam penelitian ini, pekerjaan bukan merupakan faktor yang berpengaruh signifikan, karena data yang didapatkan dari responden mayoritas sebagai seorang ibu rumah tangga $(83 \%)$. Pada penelitian yang dilakukan oleh Goel et al., (2012), didapatkan bahwa tingkat kesibukan ibu berpengaruh pada kejadian ISPA yang dinilai dari segi waktu, untuk menjaga kebersihan anak (Goel et al., 2012).

Selain faktor lingkungan sosial orang tua, faktor lain yang berpengaruh adalah karakteristik biologi dari balita. Jenis kelamin dianggap dapat mempengaruhi kekebalan tubuh balita dalam menghadapi infeksi. Menurut penelitian yang telah dilakukan Sari \& Ardianti, (2017), ada hubungan yang signifikan antara jenis kelamin dengan tingkat kejadian ISPA, dimana jenis kelamin balita perempuan lebih memiliki risiko terjadi penyakit ISPA dibandingkan dengan balita berjenis kelamin laki-laki. Hal ini diasumsikan karena daya tahan tubuh balita berjenis kelamin laki-laki lebih baik daripada balita perempuan. Dari hasil penelitian yang telah dilakukan terdapat hal cukup unik dimana terlihat bahwa frekuensi sampel didominasi oleh balita berjenis kelamin laki-laki.

Selain karakteristik biologi berupa jenis kelamin, adapula karakteristik biologi lainnya yaitu berat badan bayi pada saat lahir serta pengamatan menurut garis KMS. Hasil penelitian yang telah dilakukan memperlihatkan bahwa mayoritas balita lahir dengan berat badan diatas 2500 gram $(89 \%)$, artinya mayoritas bayi lahir dalam keadaan normal. Angka KMS (Kartu Menuju Sehat) juga terlihat mayoritas balita (84\%) berada di atas garis merah KMS. Hal ini berarti dari data kelahiran dan KMS balita di Pulau Moti dapat dikategorikan baik.

Karakteristik selanjutnya adalah variabel riwayat penyakit dan pengobatan yang telah dilalui oleh balita, diantaranya riwayat penyakit flu yang diderita balita, serta lama pemberian ASI eksklusif serta pemberian imunisasi. Hasil penelitian yang telah dilakukukan di Pulau Moti memperlihatkan bahwa balita yang mendapatkan imunisasi lengkap (BCG, DPT, Polio, Campak, dan Hepatitis) sebesar $81 \%$. Angka ini cukup tinggi karena kesadaran orang tua balita mengenai pentingnya imunisasi dikategorikan sudah baik, namun demikian perlu ditingkatkan lagi hingga di angka 100\%. Pemberian ASI eksklusif juga sudah mencapai angka $76 \%$. Data frekuensi balita yang mengalami flu dalam kurun waktu satu tahun terakhir angkanya masih tinggi yaitu sebesar 95\%. Hal ini menunjukkan bahwa pemberian ASI 


\section{TECHNO: Vol. 09 (01) Mei 2020}

eksklusif dan pemberian imunisasi pada balita tidak mempengaruhi frekuensi kejadian flu pada balita secara signifikan.

Variabel selanjutnya yang diteliti adalah kondisi lingkungan, dimana terdapat 20 poin yang terdapat pada kuesioner penelitian. Dalam poin pertanyaan kuesioner, terdapat 4 poin penting yang dapat mengidentifikasi penyebab utama tingginya tingkat kejadian ISPA pada balita di Pulau Moti. Yang pertama yaitu kamar tidur dihuni lebih dari 2 orang. Hasil analisis data diperoleh bahwa, dari 100 responden terdapat $88 \%$ persen responden yang kamar tidurnya dihuni lebih dari 2 orang dan luas kamar tidur responden mayoritas (77\%) luasnya 9 $\mathrm{m}^{2}$. Hal ini sangat berpengaruh terhadap kualitas udara di dalam ruang kamar. Menurut Depkes (2000) kepadatan hunian yaitu rasio luas lantai seluruh ruangan dibagi jumlah penghuni minimal $8 \mathrm{~m}^{2} /$ orang (Harisun et al., 2019). Luas kamar tidur minimal $8 \mathrm{~m}^{2} /$ orang dan tidak dianjurkan digunakan lebih dari dua orang tidur dalam satu ruang tidur, kecuali anak dibawah umur 5 tahun. Hal tersebut dilakukan dengan pertimbangan kualitas udara di dalam ruang tidur serta dikhawatirkan apabila terdapat anggota keluarga yang mengidap penyakit menular seperti flu tidak akan menularkan ke anggota keluarga lainnya utamanya pada balita.

Selain itu, faktor lingkungan lainnya yang berpengaruh adalah apabila ruangan di sekitar rumah balita tersebut berdebu. Kondisi lingkungan rumah yang berdebu dapat mempengaruhi kesehatan pernafasan balita, mengingat sistem pernafasan balita belum sesempurna manusia dewasa. Apabila debu yang masuk ke dalam sistem pernafasan balita mengandung zat yang berbahaya, maka akan menimbulkan infeksi salah satunya adalah ISPA. Data responden yang dikumpulkan dari kuesioner terdapat sekitar $80 \%$ orang tua yang lingkungan sekitar rumahnya berdebu. Berdasarkan penelitian yang dilakukan oleh Wulandhani didapatkan besar resiko anak terkena ISPA memiliki OR=1,228 pada rumah yang berdebu dan jarang dibersihkan dibandingkan dengan rutin dibersihkan (Wulandhani \& Purnamasari, 2019).

Faktor lingkungan lainnya adalah pengunaan bahan bakar untuk memenuhi kebutuhan rumah tangga, seperti untuk memasak menggunakan bahan kayu bakar dan arang. Sebanyak $79 \%$ reponden masih menggunakan bahan bakar yang menghasilkan asap yang tentunya sangat berbahaya baik bagi orang tua balita maupun bagi balita itu sendiri, sehingga faktor risiko terjadinya ISPA semakin meningkat. Hal itu semakin diperparah oleh ketidaksadaran orang tua tentang bahaya yang mengintai balita, apabila setiap hari menghirup asap dari sisa bahan bakar rumah tangga.

Pada penelitian ini telah ditemukan beberapa faktor penyebab kejadian ISPA yang berasal dari berbagai variabel, tetapi faktor yang sangat mempengaruhi mengapa prevalensi kejadian ISPA pada balita tetap tinggi di Pulau Moti adalah kebiasaan merokok anggota keluarga. Telah diketahui bersama bagaimana bahaya yang ditimbulkan oleh paparan asap rokok, mulai dari penyakit pernafasan seperti ISPA, hingga kanker paru-paru yang siap mengintai kapan saja. Data responden yang didapatkan pada penelitian ini didapatkan angka $81 \%$ balita, hidup pada keluarga yang memiliki kebiasaan merokok. Asap rokok mengandung racun yang sangat berbahaya bagi pernafasan, yang bila terakumulasi dalam saluran pernafasan (terutama balita), akan mengakibatkan penyakit-penyakit terutama yang berhubungan dengan sistem pernafasan, salah satunya yaitu penyakit ISPA. 


\section{KESIMPULAN}

Ditemukan beberapa variabel yang mempengaruhi tingkat kejadian ISPA di pulau Moti. Di antara variabel yang ditemukan, faktor lingkunganlah yang memiliki pengaruh terbesar dalam tingkat kejadian ISPA pada balita di Pulau Moti. Faktor risiko yang berpengaruh terhadap kejadian ISPA pada balita di Pulau Moti adalah faktor lingkungan, yaitu tingkat kepadatan hunian, kondisi rumah yang berdebu, penggunaan kayu bakar sebagai bahan bakar untuk memasak, serta kebiasaan merokok anggota keluarga dalam rumah. Faktor jenis kelamin serta pemberian imunisasi dan ASI eksklusif tidak berpengaruh terhadap kejadian ISPA pada balita di Pulau Moti.

\section{UCAPAN TERIMA KASIH}

Ucapan terima kasih disampaikan kepada Universitas Khairun yang telah mendanai penelitian ini melalui skema PKUPT tingkat Fakultas Kedokteran tahun anggaran 2019.

\section{DAFTAR PUSTAKA}

Dinas Kesehatan Provinsi Maluku Utara. 2014. Profil Kesehatan Provinsi Maluku Utara Tahun 2014. Dinkes Provinsi Malut, Ternate

Goel, K., Ahmad, S., Agarwal, G., Goel, P., \& Kumar, V. (2012). A Cross Sectional Study on Prevalence of Acute Respiratory Infections (ARI) in Under-five Children of Meerut District. India. J Comm Med Health Educ, 2(9), 176.

Harisun, E., Conoras, M. A. M. S., \& Darwis, M. (2019). Identifikasi dan Penanganan Kawasan Kumuh pada Kelurahan Makassar Timur. TECHNO: Jurnal Penelitian, 8(1), 259-270.

Jamison, D. T., Breman, J. G., Measham, A. R., Alleyne, G., Claeson, M., Evans, D. B., Jha, P., Mills, A., \& Musgrove, P. (2006). Disease control priorities in developing countries. The World Bank.

Kementerian Kesehatan RI. 2013. Riset Kesehatan Dasar 2013. Badan Penelitian dan Pengembangan Kesehatan Kemenkes RI, Jakarta.

Laporan Tahunan Puskesmas Pulau Moti Tahun 2017-2019

Laporan Penyakit dengan Kasus Tertinggi di Puskesmas Moti tahun 2017-2019

Lebuan, A. W., \& Somia, A. (2014). Faktor yang Berhubungan dengan Infeksi Saluran Pernapasan Akut Pada Siswa Taman Kanak-Kanak di Kelurahan Dangin Puri Kecamatan Denpasar Timur Tahun 2014. E-Jurnal Medika Udayana, 6(6).

Marciniuk, D., Ferkol, T., Nana, A., de Oca, M. M., Rabe, K., Billo, N., \& Zar, H. (2014). Respiratory Diseases in the World. Realities of today--opportunities for tomorrow. African Journal of Respiratory Medicine Vol, 9(1).

Mucia, M., Salvago, P., Brancato, A., Cannizzaro, C., Cannizzaro, E., Gallina, S., Ferrara, S., La Mattina, E., Mule, A., Plescia, F., \& others. (2015). Upper Respiratory Tract Infections in Children: From Case History to Management. Acta Medica Mediterranea, 31(2), 419424. 
Novesar, A. R., Darwin, E., \& Yani, F. F. (2014). Pola Kejadian ISPA pada Balita di Wilayah Kerja Puskesmas Anak Air Padang Tahun 2012. Jurnal Kesehatan Andalas, 3(3).

Rahman, R., \& Ma'wa, S. N. (2015). Pemetaan Penyakit Berbasis Lingkungan Di Pulau Saugi Kabupaten Pangkep. Healthy Tadulako Journal (Jurnal Kesehatan Tadulako), 1(2), 7278.

Riset Kesehatan Dasar. 2013. Badan Penelitian dan Pengembangan Kesehatan Kementerian RI

Sari, N. I., \& Ardianti, A. (2017). Hubungan Umur dan Jenis Kelamin Terhadap Kejadian Infeksi Saluran Pernapasan Akut (ISPA) pada Balita di Puskesmas Tembilahan Hulu. AnNadaa: Jurnal Kesehatan Masyarakat, 4(1), 26-30.

Solomon, O., Odu, O., Amu, E., Solomon, O., Bamidele, J., Emmanuel, E., \& Parakoyi, B. D. (2018). Prevalence and Risk Factors of Acute Respiratory Infection Among Under Fives in Rural Communities of Ekiti State Nigeria. Global Journal of Medicine and Public Health, 7(1), 12.

Taksande, A. M., \& Yeole, M. (2015). Risk factors of Acute Respiratory Infection (ARI) in Under-fives in a Rural Hospital of Central India. Journal of Pediatric and Neonatal Individualized Medicine (JPNIM), 5(1), e050105.

Wulandhani, S., \& Purnamasari, A. B. (2019). Analisis Faktor Risiko Kejadian Infeksi Saluran Pernapasan Akut ditinjau dari Lingkungan Fisik. Sainsmat: Jurnal Ilmiah Ilmu Pengetahuan Alam, 8(2), 70-81. 